\title{
Discussing a Forensic Dental Examination of 1861 - A Scientific and Historic Overview
}

\section{Scheila Mânica*}

School of Medicine and Dentistry, Queen Mary University of London, UK

*Corresponding author: Scheila Mânica, School of Medicine and Dentistry, Queen Mary University of London, UK, Tel: 4478956245367; E-mail: scheilamanica@hotmail.com

Rec date: March 23, 2015 Acc date: April 07, 2015 Pub date: April 13, 2015

Copyright: (c) 2015 Mânica S. This is an open-access article distributed under the terms of the Creative Commons Attribution License, which permits unrestricted use, distribution, and reproduction in any medium, provided the original author and source are credited.

\begin{abstract}
This work is a discussion on a report of dental examination and exclusion made by a British dentist Francis Robertus Lloyd on 30th April 1861. The report entitled: 'Dentistry as a mean of Identification' was published in the 'British Journal of Dental Science' under the section 'Miscellanea' in 18631; Mr Lloyd was contacted by the Indian authorities in order to identify a skull and he may well be the first British dentist to officially report a dental examination in an academic journal. The aims of this discussion are to briefly analyze the difficulties of access to scientific techniques in that century and to provide Mr Lloyd recognition of his report in the history of Forensic Dentistry.
\end{abstract}

Keywords: Dental examination; History of Forensic Dentistry

\section{Introduction}

Establishing a person's identity may require an interdisciplinary approach including dental science [1,2]. The various resources employed include radiographs, photographs, dental charts and DNA $[3,4]$. Mr Francis Robertus Lloyd practiced dentistry in the East Indies and, at certain day, he received a skull from the Punjab authorities in order to give an opinion on its probable age and ethnic origin (European or Asian). Speculations indicated that the skull belonged to a German citizen aged 27 years (Mr S.) engaged in a geological survey in Northern India and was supposedly killed by one of the native chiefs. A selection of the most relevant findings present in his conclusive report were selected (in italic) followed by the author's discussion.

\section{Past Dental Investigation made by a British dentist in 1800's}

Published forensic cases involving the work of British dentists in the 19th century are few: in 1814, the case of Mrs J McAlister which was the first case in Britain where members of the dental profession were cited as expert witnesses - a denture fitting on the deceased resolved the case; in 1831, the case of Mrs Caroline Walsh where two similar women were assumed to be dissimilar by their front teeth therefore convicting a third woman of murder; and in 1850, a double murder in Scotland where the suspect's teeth were found comingled with the victim's teeth [5].

\section{Dental Profiling}

It is well known that Forensic Odontology plays an important role in the identification of human remains based on the characteristics of teeth and concordant points between ante- and post-mortem reconciliation [6]. Dental profiling might provide some predictions about the deceased's habits and ethnicity and it may be used when investigating authorities are unable to supply any ante-mortem dental record to aid the forensic dentists' work [7-9].
Mr Lloyd's report was a dental profiling because he was unable to compare the post-mortem dentition to an ante-mortem record. Radiographs, particularly, can be used to predict the age, however, the $\mathrm{X}$-ray would only be discovered accidentally by a German scientist named Dr. Wilhelm Conrad Röntgen, in $1895[9,10]$. The conclusions were based solely on the dental examination since studies on anthropometric measurements had not yet been performed; for instance, the work of Alphonse Bertillon, a French criminologist who first developed a system of physical description of head and face, in 1879 [11]. It should also be noted that the skull can be used to assess the ageing process through closure of skulls sutures in adulthood, which is not a reliable method; additionally, the shape of the skull and mandible may offer distinctive features that aid the prediction of the sex of the individual [12]. Modern skull analysis is the basis of facial reconstruction which constructs a model of the face using the skull as a base like the use of a photographic image of the skull superimposed on an ante-mortem photo of the person [12].

\section{Findings and discussions of Mr Lloyd's report}

"The teeth of the superior maxilla are fourteen in number. The two missing ones are the second and third molars of the left side..."

While the number of teeth present and features of their size, shape and arrangement may be sufficiently distinctive to allow identification, it is more often the dental treatment such as restorative work which leads to identification [11]. It is anticipated that restorative treatments were not present in the teeth of the skull being analyzed. Mention should be made that, in the 1800's, new dental materials quickly followed the rhythm of the recognition of dentistry as practice. By this time, the most widely used dental filling material was silver amalgam followed by porcelain, while composites came to the scene in the $20^{\text {th }}$ century [13]

It is worth pointing out that developmental stages of the teeth are accurate in determining sub-adult ages, and, third molar development is used to predict age to young adults even though it might present variability [4]. After the emergence of second permanent molar which 
is around 11-13 years of age with a further period of about 2 years root development and the only remaining teeth to develop are the third molars which may emerge between the ages of 17-21 years followed by subsequent root completion [14].

Mr. Lloyd also did not mention any tooth notation code or nomenclature. The first official method for recording the positions of the teeth in the oral cavity was developed by an Austrian dentist named Adolph Zsigmondy, in 1861. He numbered the eight permanent teeth with Arabic numbers 1 to 8 from the midline backwards in each quadrant, therefore breaking the tradition of writing lengthy Latin names $[9,15,16]$.

"....the sockets of which are partially obliterated by the deposition of osseous matter from the deep parts, and the loss of substance by absorption of the alveolar margins. These teeth appear to have been lost some time prior to the person's death."

An important biological phenomena should be considered regarding ante mortem tooth loss: tooth loss is manifested by alveolar ridges and sockets with rounded and smooth edges, however, postmortem tooth loss presents sharp socket edges.18 This distinction is paramount in the reconciliation of dental chartings. Nevertheless, it is scientifically difficult to time the process of socket healing and most of the studies were performed on animals; however, a study on human single-rooted teeth showed that, after extraction, a blood clot filled the socket and after 7 days, the clot is replaced with granulation tissue. After 20 days, the granulation tissue is replaced by collagen and bone began forming. At 5 weeks on average, 2/3 of the socket had filled with soft tissue and it takes 24-35 days to completely cover the socket. All stages of bone regeneration progress from the apex and periphery and proceeded to the center of the socket [17]. Empty dental sockets can be used in a technique of post-mortem reconstruction where they are filled with radiopaque material that shows white on radiographs delimiting the shapes of the individual roots to compare with dental records; yet, the relative individualizing value of the roots is low (to peri- and post- mortem tooth loss) $[18,19]$.

"..there are fifteen inferior teeth; the missing tooth is the right central incisor...the vacant space is nearly as large as the width of the remaining central incisor of the left side which leads to the inference that it was lost after the eruption of the wisdom teeth, which rarely make their appearance before the 18 year...the pressure exercised would have tended to close or greatly diminish the space left by the missing incisor."

Third molar mesial pressure has been studied since 1859 and even though a few studies support the late anterior teeth crowding association with mesial movement of posterior teeth, long term studies do not suggest evidence of this effect $[20,21]$. In short, the crowding might be caused by interaction of factors such as: facial growth pattern, continuing late growth rotations and parafunctional soft tissue pressures [22]. Surprisingly, in 1920, a formula that estimates physical stature was created from the proportion of the lateral dimensions of the crowns of the lower incisors and canines [23]. Moreover, an analysis of mandibular canine dimensions was thought to show the presence of sex dimorphism [24].

"...it is most probable that the two missing molar teeth of the upper jaw and the front tooth of the lower jaw were at some period extracted by a professional man, and might be useful as a means of identification;"
The quote of 'professional man' might show the lack of women working in Dentistry. In Britain, before the 19th century there was a marked increase in the number of practicing dentists but there was no control of the standards of apprenticeship. By the year of 1860 , teaching schools in Dentistry began followed by Dental Reform Committee which regulated dentistry through the Dentists Act of 1878 [25]. The first woman to qualify as a dentist in the United Kingdom was Lilian Lindsay who received her Licentiates in Dental Surgery (LDS) from Edinburgh in 1895 [26]. Other finding is that the dentist was aware that the advent of tooth extraction could be used to differentiate the dental state of the individual.

"...it is most improbable that in a mouth in which the teeth are so remarkably developed and so firm in their sockets they should have been lost by any other means...for their loss if we presume the deceased to have been much older, as the diminished vitality of the surrounding tissues of the tooth, as age advances..."

In a young person the crests of the bone supporting the teeth usually lie within about $2 \mathrm{~mm}$ of the cervical margin of the teeth, so that usually only this length of the root of a tooth is exposed in the young skeleton. With ageing, more of the root is exposed attributable to inflammation of the junction of the tooth and gum or not [12]. Further, post mortem tooth loss is common in cases where decomposition is advanced and front teeth, having only one root, are more frequently lost than back teeth (bicuspids and molars) [19].

"... and the partial and sometimes complete ossification of the pulp, as it recedes before the encroachment made upon its containing cavity from loss of substance on the masticating surface, may each or both cause alveolar abscess and loosening and ultimate ejection of the tooth so affected...there is not the slightest appearance of caries or defective development.."

Severe attrition of the teeth may be caused by unusual occlusions, grinding of the teeth (bruxism) or type of diet. Men usually exhibit more attrition than women at a given age and so the phenomenon may aid in sex estimation, but this is a very poor discriminant [12]. Pulpal response to trauma is characterized by deposition of hard tissue in the root canal space and the affected crown is darker in color because of a decrease in dentine translucency [27]. Moreover, failure to protect the pulp can lead to infection caused by remaining bacteria. In any case, the vitality of the dental pulp of an aged person appears to be weaker than that of a young person [28]. Discussing about caries, it is important to note that just in the 1870's, a foot-powered drill and a fully adjustable chair were created by an innovator called James Beall Morrison in order to treat caries more effectively [29]. In early 1900's (1908-1912), Greene Vardiman Black standardizes cavity preparation, which means that those events happened years after this case of dental investigation [30].

"...the right superior central incisor is one eight broader on its labial aspect than its fellow on the left side of the median line....not only diseases but peculiarities of development in different parts of the human frame, and in members of the same family, are frequently so strongly pronounced that the relationship cannot be doubted......one at least of the surviving brothers would exhibit the same peculiarity."

The statement referred to this tooth could be interpreted as macrodontia which is a rare shape anomaly where the tooth is physically larger than normal and it is usually associated with systemic disturbances or syndromes [31]. The isolated form of macrodontia has been rarely reported and the prevalence in permanent teeth is $0.03-$ $1.9 \%$ with a higher frequency in males [32]. The teeth most frequently 
affected by this type of macrodontia are the maxillary first incisor and canine, and has been rarely reported to involve premolar and third molar. The incidence is rare enough to be useful in identification procedures [12]. Mr Lloyd's comment is noteworthy when considered the possible genetic relation.

"...the structure of the teeth is perfect regards thickness of enamel, soundness and development, leads me to conclude, from experience, that such considerable loss of substance could not have taken place in a person less than forty or forty-five years of age."

Age estimation in adults may be possible through the analysis of: the amount of secondary dentine deposited around the pulp chamber, the level of attachment of the periodontal tissues, the extent of secondary cementum deposition, the extent of sclerotic or translucent dentine spreading from the apex of the tooth examining, the amount of tooth wear and the colour of the teeth (teeth tend to darken with age) $[7,8]$.

"I strongly suspect, from the teeth, that this is the head of a native of India who subsist chiefly on grain of various descriptions.....This gritty substances would naturally wear away the gridding surfaces of the teeth, much sooner ...than where the food consisted chiefly of animal and vegetable substances, as in the case of Europeans.... and their teeth are generally much incrusted with salivary calculus, which I observe is freely deposited on the teeth of the head I am describing."

Rustic means of grain production produced very abrasive foodstuffs due to the incorporation of fine grit, accelerating attrition and subsequent fracture of child and adult teeth [17]. Interestingly, a grade system of molar wear for age estimation was created by Miles33 followed by Brothwell who assessed pre-medieval British skulls (17 $45+\mathrm{yrs})$ and thus appropriate to archaeological specimens $[33,34]$. More recently, because of the processed food present in industrialized countries, the occlusal attrition has been reduced [30].

"Captain $\mathrm{H}$, who was intimately acquainted with $\mathrm{Mr} \mathrm{S}$., informs me that the gentleman had a regular set of teeth, whereas the teeth in the head submitted to me for examination are far from being regular, as the cutting edges of the incisors and the grinding surfaces of the molars present several curved lines...trusting my remarks may be of some use in deciding the question as to whether this is or is not the head of Mr S."

Smile photographs may be of some use of information with the potential to help solve certain cases of human identification; therefore, the inclusion of this information regarding the visual memory of Captain $\mathrm{H}$ was of some value [35].

\section{Conclusion}

Despite the fact that Mr Lloyd was not able to make use of forensic tools and techniques in order to accomplish a complete dental profiling, his final conclusion excluding the possibility of the skull being of Mr S can also be merit simply as an exclusion and could not be classed as an identification, since the identity of the skull is not determined.

\section{About the author of the report}

According to the Dental Register Archive of the British Dental Association Museum, Mr Francis Robertus Lloyd was first registered in the British Dental Register on 20th January 1879. He held no qualifications but he was registered as he had been in practice before 22nd July 1878. In 1879 he practiced in Agra, East Indies and he was last registered in 1890 .

\section{Acknowledgments}

I would like to express my gratitude to Mr Roland Hopwood and Mr Mehzebin Adam, volunteer and museum assistant of the British Dental Association Museum, respectively, for providing the information about Mr Lloyd in the Dental Register Archive. This paper is dedicated to the memory of Mr Lloyd FL.

\section{References}

1. Lloyd FR (1863) Dentistry as a mean of identification. Br J of Dent Sc 6: 406-410.

2. Avon SL (2004) Forensic Odontology: the roles and responsibilities of the dentist. J Can Dent Assoc 70: 453-458.

3. Saxena S, Sharma P, Gupta N (2010) Experimental studies of forensic odontology to aid in the identification process. J Forensic Dent Sci 2: 6976.

4. Pretty IA, Sweet D (2001) A look at forensic dentistry--Part 1: The role of teeth in the determination of human identity. Br Dent J 190: 359-366.

5. Hill IR, keiser-Nielsen S, Vermylen Y, Free E, de Valck E (1984) Forensic Odontology - its scope and history. Leuven. Academische Cooperatif s.v.

6. Acharya AB, Taylor JA (2003) Are a minimum number of concordant matches needed to establish identity in forensic odontology? J Forensic Odontostomatol 21: 6-13.

7. Gustafson G (1950) Age Determination on Teeth. J Amer Dental Assoc 41: 45-54.

8. Thompson T, Black S (2006) Forensic Human Identification - An Introduction. London. CRC Press.

9. Clark DH, Sainio P (1992) Practical Forensic Odontology. Oxford. Wright.

10. Glasser O (1993) Wilhelm Conrad Röntgen and the Early History of the Roentgen Rays. San Francisco: Norman Publishing.

11. Kaluszynski M (2001) Republican Identity: Bertillonage as government Technique. In Documenting Individual Identity: The Development of State Practices since the French Revolution 123-139.

12. Whittaker DK, MacDonald DG (1989) A Colour Atlas of Forensic Dentistry.

13. Gladwin MA, Bagby MD, Gladwin MA (2004) Clinical aspects of dental materials: Theory, practice, and cases.

14. Panchbhai AS (2012) Radiographic Evaluation of Developmental Stages of Third Molar in Relation to Chronological Age as Applicability in Forensic Age Estimation. Dentistry S1:002.

15. Harris EF (2005) Tooth-Coding Systems in the Clinical Dental Setting. Dental Anthropology 18: 43-49.

16. Huszar G (1989) The role of the life and works of Adolf Zsigmondy and Ottó Zsigmondy in the history of dentistry. Fogorv Sz 82: 357-363.

17. Herschaft EE, Alder ME, Ord DK (2007) Manual of Forensic Odontology, American Society of Forensic Odontology 4.

18. Steiner GG, Francis W, Burrell R, Kallet MP, Steiner DM, et al. (2008) The healing socket and socket regeneration. Compend Contin Educ Dent 29: 114-116.

19. Bowers CM (2004) Forensic Dental Evidence: an investigator's handbook. San Diego. Elsevier Academic Press.

20. Harradine NW, Pearson MH, Toth B (1998) The effect of extraction of third molars on late lower incisor crowding: a randomized controlled trial. Br J Orthod 25: 117-122.

21. Sumitra, Tandur AP (2005) Third Molars and Late Mandibular Incisor Crowding - A Review. J Ind Orthod Soc 38: 100-111.

22. Samspon WJ (1995) Current controversies in late incisor crowding. Ann Acad Med Singapore 24: 129-137. 
Citation: Manica S (2015) Discussing a Forensic Dental Examination of 1861 - A Scientific and Historic Overview. J Forensic Res 6: 281. doi:

Page 4 of 4

23. Carrea JU (1920) Ensayos odontometricos. Tese (Doutorado) - Escuela de Odontologia de la Facultad de Ciências Médicas, Buenos Aires.

24. Khangura RK, Sircar K, Singh S, Rastogi V (2011) Sex determination using mesiodistal dimension of permanent maxillary incisors and canines. J Forensic Dent Sci 3: 81-85.

25. British Dental Association (BDA) (2010) Dentistry from Ancient to Modern: Development of the profession.

26. Heines CMC (2001) International women in science: a biographical dictionary to 1950. CITY. ABC-CLIO.

27. Oginni AO, Adekoya-Sofowora CA, Kolawole KA (2009) Evaluation of radiographs, clinical signs and symptoms associated with pulp canal obliteration: an aid to treatment decision. Dent Traumatol 25: 620-625.

28. Ward J Vital (2002) pulp therapy in cariously exposed permanent teeth and its limitations. Aust Endod J 28: 29-37.

29. Ring ME, Hurley N, Morrison JB (2000) the visionary who revolutionized the practice of dentistry. J Am Dent Assoc 131: 1161-1167.
30. Gilmour WH (1935) Principles Concerned in Tooth-Cavity Preparation (Section of Odontology). Proc R Soc Med 28: 1433-1446.

31. Stimson PG, Senn DR (2010) Forensic Dentistry, 2nd Edition. CRC Press.

32. Canoglu E, Canoglu H, Alper A, Cehreli ZC (2012) Isolated bilateral macrodontia of mandibular second premolars: A case report. Eur J Dent 6: $330-334$.

33. Miles, AEW. Assessment of age from the dentition. Proceedings of the Royal Society of Medicine 51: 1057-1050.

34. Koçani F, Kamberi B, Dranqolli J, Luci K, Peja F (2012) Occlusal tooth wear in human skulls of antique period from Vendenis and Municipium Dardanorum DD, Kosovo. Open Journal of Stomatology 2: 1-11.

35. Silva RF, Pereira SD, Prado FB, Daruge E (2008) Forensic odontology identification using smile photograph analysis-case reports. J Forensic Odontostomatol 26: 12-17. 